\title{
Warburgia ugandensis Leaf and Bark Extracts: An Alternative to Copper as Fungicide against Downy Mildew in Organic Viticulture?
}

\author{
Christian Kraus ${ }^{1, *} \mathbb{D}$, Rada Abou-Ammar ${ }^{2} \mathbb{D}$, Andreas Schubert ${ }^{2}$ and Michael Fischer ${ }^{1}$ \\ 1 Julius Kühn-Institute, Federal Research Centre of Cultivated Plants, Plant Protection in Fruit Crops and \\ Viticulture, 76833 Siebeldingen, Germany; michael.fischer@julius-kuehn.de \\ 2 Fraunhofer Institute for Cell Therapy and Immunology (IZI), 04103 Leipzig, Germany; \\ rada.abou-ammar@izi.fraunhofer.de (R.A.-A.); andreas.schubert@izi.fraunhofer.de (A.S.) \\ * Correspondence: christian.kraus@julius-kuehn.de; Tel.: +49-6345-41-159
}

\section{check for} updates

Citation: Kraus, C.; Abou-Ammar, R.; Schubert, A.; Fischer, M. Warburgia ugandensis Leaf and Bark Extracts: An Alternative to Copper as Fungicide against Downy Mildew in Organic Viticulture?. Plants 2021, 10, 2765. https://doi.org/10.3390/ plants10122765

Academic Editors: Pablo

Martín-Ramos, Jesús Martín-Gil and Vicente Gonzalez Garcia

Received: 25 November 2021 Accepted: 8 December 2021 Published: 14 December 2021

Publisher's Note: MDPI stays neutral with regard to jurisdictional claims in published maps and institutional affiliations.

Copyright: (c) 2021 by the authors. Licensee MDPI, Basel, Switzerland. This article is an open access article distributed under the terms and conditions of the Creative Commons Attribution (CC BY) license (https:// creativecommons.org/licenses/by/ $4.0 /)$.

\begin{abstract}
In organic viticulture, copper-based fungicides are commonly used to suppress Downy Mildew infection, caused by the oomycete Plasmopara viticola. However, the frequent and intensive use of such fungicides leads to accumulation of the heavy metal in soil and nearby waters with adverse effects on the ecosystem. Therefore, alternative, organic fungicides against Downy Mildew are urgently needed to reduce the copper load in vineyards. In this study, the use of Warburgia ugandensis Sprague (Family Canellacea) leaf and bark extracts as potential fungicides against Downy Mildew were evaluated. In vitro (microtiter) and in vivo (leaf discs, seedlings) tests were conducted, as well as field trials to determine the efficacy of the extracts against Downy Mildew. The results revealed an $\mathrm{MIC}_{100}$ of $500 \mu \mathrm{g} / \mathrm{mL}$ for the leaf extract and $5 \mu \mathrm{g} / \mathrm{mL}$ for the bark extract. Furthermore, experiments with leaf discs and seedlings demonstrated a strong protective effect of the extracts for up to $48 \mathrm{~h}$ under (semi-) controlled conditions. However, in field trials the efficacy of the extracts distinctly declined, regardless of the extracts' origin and concentration.
\end{abstract}

Keywords: botanical; Downy Mildew; Plasmopara viticola; viticulture; Warburgia ugandensis; plant extract; plant protection

\section{Introduction}

Downy Mildew (DM) of grapevine, caused by the oomycete Plasmopara viticola, is one of the most threatening and harmful diseases in viticulture. Ever since it was introduced to European vineyards in 1876, probably by shipping of American grape cuttings, this pathogen caused massive yield losses in vine-growing regions all over the world [1,2]. Therefore, protective measures were urgently needed in the second half of the 19th century to control this disease, and it was a coincidence that led to the first plant protection product (PPP) against DM, the Bordeaux mixture [3]. Copper cations $\left(\mathrm{Cu}^{2+}\right)$, which were the actual active substance against $P$. viticola in the mixture, then served as a basis for PPP to combat DM all over the world, mainly as $\mathrm{Cu}$ oxychloride, $\mathrm{Cu}$ sulfate and $\mathrm{Cu}$ hydroxide [4]. Furthermore, even almost 150 years after its discovery and after the development of other, more effective PPPs against DM, copper-based fungicides are still widely used in vineyards, especially in organic viticulture $[2,5,6]$.

Although $\mathrm{Cu}$ is of considerable importance for crop protection, due to its high efficacy and reduced resistance risk, it has become a growing public concern over the last decades [6]. The continuous and intensive application of $\mathrm{Cu}$-based fungicides leads to an accumulation of the heavy metal in agricultural soils and nearby waters and as a result negatively affects the ecosystems [2,7-10]. In organic viticulture, this problem is even more severe since alternatives with comparable efficacies to copper are rare presently or even non-existing since the ban of phosphonates [11]. Therefore, more PPPs are strongly needed 
to extend the "toolbox" for protection against DM and with that, reducing the cooper input in the environment [12].

One possible source of PPPs for organic agriculture is extracts derived from plant parts (e.g., leaves, bark, roots, fruits) or whole plants, so-called botanicals [13-19]. The interest in botanicals, not only as pesticides in agriculture but also as pharmaceuticals, massively increased in the last decades mostly due to public concerns regarding off-target effects by synthetic pesticides/drugs [20-23]. Also in viticulture, several plant extracts were evaluated regarding their efficacy against DM, with promising results: Salvia officinalis [24], Vitis vinifera [25], Juncus effusus [26], Larix decidua [27], Verbesina lanata [28], Magnolia officinalis [29], Yucca schidigera, Glycyrrhiza glabra [30]. However, despite strong efforts, so far, no PPP based on plant extracts could fulfill all criteria for a highly effective fungicide against DM in viticulture.

Warburgia ugandensis Sprague (Family Canellaceae; WU), commonly known as “Uganda Green Heart Tree", is an evergreen plant, which is mainly distributed in East and South Africa [31-33]. For generations, traditional healers were using WU extracts made of bark, roots or leaves to treat different kinds of diseases/ailments like malaria, tuberculosis, skin diseases, ulcers, lung problems or intestinal worms, to name a few [31,34-37]. The reason for its high and diverse therapeutic potential is linked to a broad arsenal of phytochemicals belonging to the groups of drimane sesquiterpenes, tannins and mannitol $[33,38,39]$. Three of these phytochemicals are polygodial, warburganal and muzigadial, all showing antifungal activity against Saccharomyces cerevisiae, Candida albicans, C. utilis, and Sclerotinia libertiana [40,41]. Also, against the soil pathogens Fusarium oxysporum, Alternaria passiflorae, and Aspergillus niger, WU extracts showed inhibitory effects [42]. Besides antifungal properties, extracts made of WU exhibit further activities, e.g., antibacterial, antimycobacterial and antiplasmodial activities [31,34,43-46]. Concerning toxicity, a study conducted on mice classified WU extracts as non-cytotoxic and showed a lethal dose of $\left(\mathrm{LD}_{50}\right)>5000 \mathrm{mg} / \mathrm{kg}$ body weight [47]. Although highly concentrated WU extract was toxic to VERO cells, no toxicity was found by mammalian macrophage cells [35,48,49]. As a conclusion, extracts made of WU may be used as powerful active compounds in future PPPs against a wide variety of pathogens with minimal health risks. These properties are ideal requirements for an application of the extracts as fungicide in organic agriculture.

It was the aim of the present study to evaluate selected WU leaf (WLD) and bark (WBD) extracts as possible fungicide compounds against DM under in vitro and in vivoconditions. Field trials were performed to compare the efficacy of WU extracts with a commercial Cu-based PPP. The obtained results will show whether WU extracts are adequate alternatives and thus can help to decrease the cooper load in organic viticulture.

\section{Results}

\subsection{Microtiter Assay}

We tested the concentration range in which the WU extracts show an inhibitory effect against $P$. viticola. The $\mathrm{MIC}_{50}$ and $\mathrm{MIC}_{100}$ values for each extract were determined related to the zoospore behavior and the germination rate of the sporangia (Figure 1). Regarding the zoospore behavior, for the WLD, no germination $\left(\mathrm{MIC}_{100}\right)$ appeared at $500 \mu \mathrm{g} / \mathrm{mL}$. However, the zoospore mobility was still negatively affected $\left(\mathrm{MIC}_{50}\right)$ at $25 \mu \mathrm{g} / \mathrm{mL}$. The bark extract was more effective than the leaf extract with an $\mathrm{MIC}_{100}$ of $5 \mu \mathrm{g} / \mathrm{mL}$ and an $\mathrm{MIC}_{50}$ of $0.1 \mu \mathrm{g} / \mathrm{mL}$. Compared to the $\mathrm{Cu}$-fungicide, with an $\mathrm{MIC}_{100}$ of $5 \mu \mathrm{g} / \mathrm{mL}$ and an $\mathrm{MIC}_{50}$ of $0.25 \mu \mathrm{g} / \mathrm{mL}$, the WBD had the same efficacy. Also in relation to the germination rate, the $\mathrm{Cu}$-fungicide and the WBD share the same $\mathrm{MIC}_{100}$ of $5 \mu \mathrm{g} / \mathrm{mL}$. However, the $\mathrm{MIC}_{50}$ of the $\mathrm{Cu}$-fungicide was lower $(0.25 \mu \mathrm{g} / \mathrm{mL})$ compared to the WBD $(2.5 \mu \mathrm{g} / \mathrm{mL})$. For WLD, the efficacy was reduced when compared to the other two test products: at a concentration of $500 \mu \mathrm{g} / \mathrm{mL}$ all sporangia stopped germinating $\left(\mathrm{MIC}_{100}\right)$ and at a concentration of $50 \mu \mathrm{g} / \mathrm{mL}$ the germination rate could nearly be halved $\left(\mathrm{MIC}_{50}\right)$. 

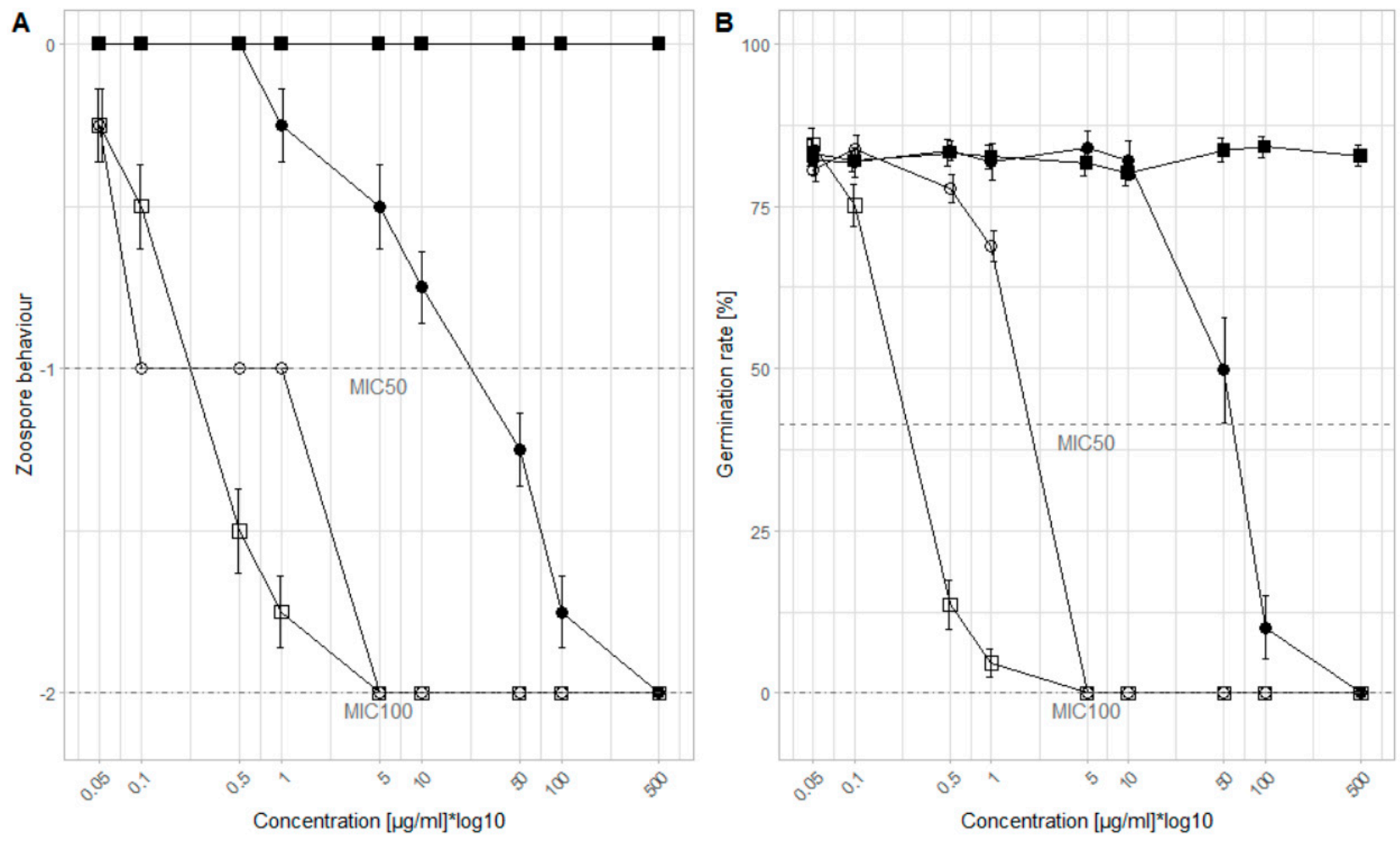

Figure 1. Results of the microtiter assays, (A) zoospore behavior and (B) germination rate of sporangia $(n=16)$ : Control (ם), Cu-fungicide $(\square)$, WLD $(\bullet)$, WBD $(\bigcirc)$. Three behavior categories were defined to measure the zoospore behavior: (0) normal zoospore motion; $(-1)$ no or unusual zoospore motion; $(-2)$ no zoospore release. Nine concentrations of each extract were selected to examine the inhibition efficacy: $0.05 ; 0.1 ; 0.5 ; 1 ; 5 ; 10 ; 50 ; 100 ;$ and $500 \mu \mathrm{g} / \mathrm{mL}$. Y-axis is $\log 10$ transformed to generate a more coherent plot. $\mathrm{MIC}_{50}$ is indicated as a dashed line, $\mathrm{MIC}_{100}$ as a dotted-dashed line.

\subsection{Leaf Disc Assay}

A leaf disc assay was chosen to test the efficacy of the WU extracts in an in vivo system. With three tested concentrations $(5,50$ and $500 \mu \mathrm{g} / \mathrm{mL}$ ) and three different infection time points $(0,24$ and $48 \mathrm{~h}$ after treatment), the WLD had a protective effect only at the highest concentration, i.e., $500 \mu \mathrm{g} / \mathrm{mL}$, and only if the inoculation took place directly after the treatment ( 0 h; Figure 2). When leaf discs were inoculated after 24 or $48 \mathrm{~h}$, respectively, the leaf discs showed full sporulation (infection severity 4). WBD treatment resulted in a full protection or no sporulation (infection severity 0 ), respectively, when using 50 and $500 \mu \mathrm{g} / \mathrm{mL}$, at $0 \mathrm{~h}$. However, long-term protection, i.e., 24 and $48 \mathrm{~h}$, only could obtained with $500 \mu \mathrm{g} / \mathrm{mL} \mathrm{WBD}$. Also, the $\mathrm{Cu}$-fungicide at $500 \mu \mathrm{g} / \mathrm{mL}$ could maintain its protective effect up to $48 \mathrm{~h}$. With $5 \mu \mathrm{g} / \mathrm{mL}$, an infection could not be impeded, but with $50 \mu \mathrm{g} / \mathrm{mL}$ at $48 \mathrm{~h}$ the severity could significantly be reduced by half. 


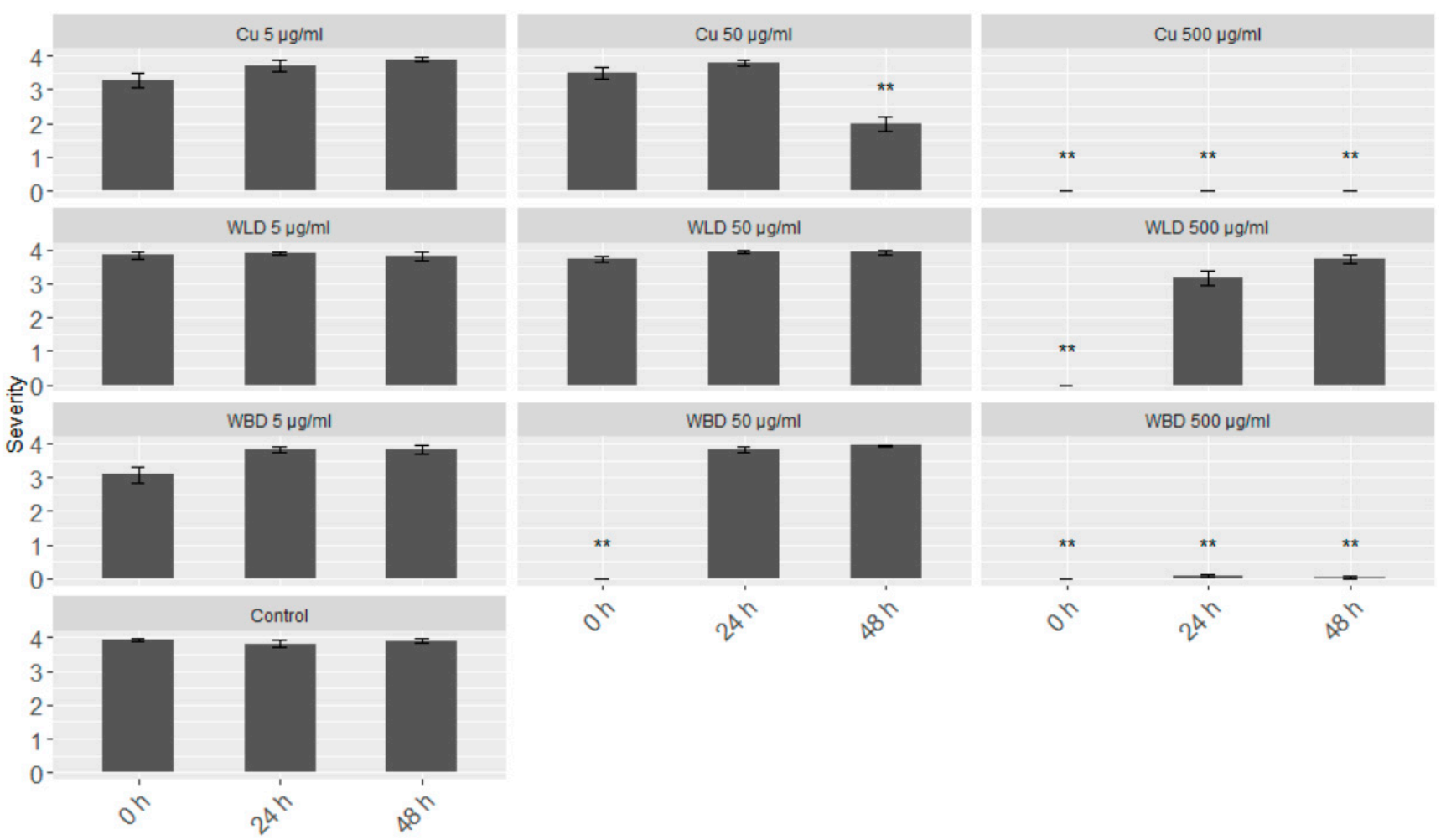

Figure 2. Merged (cv. 'Müller-Thurgau' and 'Pinot Noir') results of the leaf disc assays based on infection severity: (0) no sporulation, (1) minimal sporulation, (2) low sporulation, (3) medium sporulation, (4) full sporulation. For each treatment, three concentrations were tested $(5,50$ and $500 \mu \mathrm{g} / \mathrm{mL})$ and three different time points of sporangia inoculation $(0,24$, and $48 \mathrm{~h}$ after spraying). Treatments were Cu-fungicide ( $\mathrm{Cu}$ ), WLD, WBD and control. Welch's anova and Games-Howell test for multiple comparison: Significant differences of the treatments compared to control; ${ }^{* *} p<0.001 ; n=48$.

\subsection{Seedlings under Semi-Controlled Conditions}

A preliminary test with seedling plants, cv. 'Müller-Thurgau' and 'Pinot Noir', was performed to study the protection efficacy of the WU extracts under field conditions. Seedlings were grown in greenhouse, treated in the lab, but then placed in the field in order to simulate a natural exposure to abiotic factors (e.g., sunlight, humidity/aridity). After 24 and $48 \mathrm{~h}$, respectively, the seedlings were brought to the lab and a leaf disc assay was performed (Figure 3). While under field conditions, there was no rain, the mean temperature was $16.5^{\circ} \mathrm{C}\left(\max .=25.6^{\circ} \mathrm{C}, \min =8.3^{\circ} \mathrm{C}\right)$ and the mean relative humidity was $59.0 \%$ (max. $=88 \%$, $\min =32 \%)$.

A mean severity of around three (medium sporulation) was observed for both time points ( 24 and $48 \mathrm{~h}$ ) of the control treatment. Seedlings treated with $500 \mu \mathrm{g} / \mathrm{mL}$ of the $\mathrm{Cu}$-fungicide showed a minimum sporulation (1) at $24 \mathrm{~h}$ and almost no sporulation (0) at $48 \mathrm{~h}$. Compared to the control, when treated with $1000 \mu \mathrm{g} / \mathrm{mL} \mathrm{WLD}$, the DM severity could be slightly reduced: at $24 \mathrm{~h}$ by $22 \%$ and at $48 \mathrm{~h}$ by $40 \%$. Using $500 \mu \mathrm{g} / \mathrm{mL} \mathrm{WBD,} \mathrm{the}$ severity, compared to the control treatment, could be reduced by $86 \%(24 \mathrm{~h})$ and $98 \%(48 \mathrm{~h})$, respectively, resulting in almost no sporulation. 

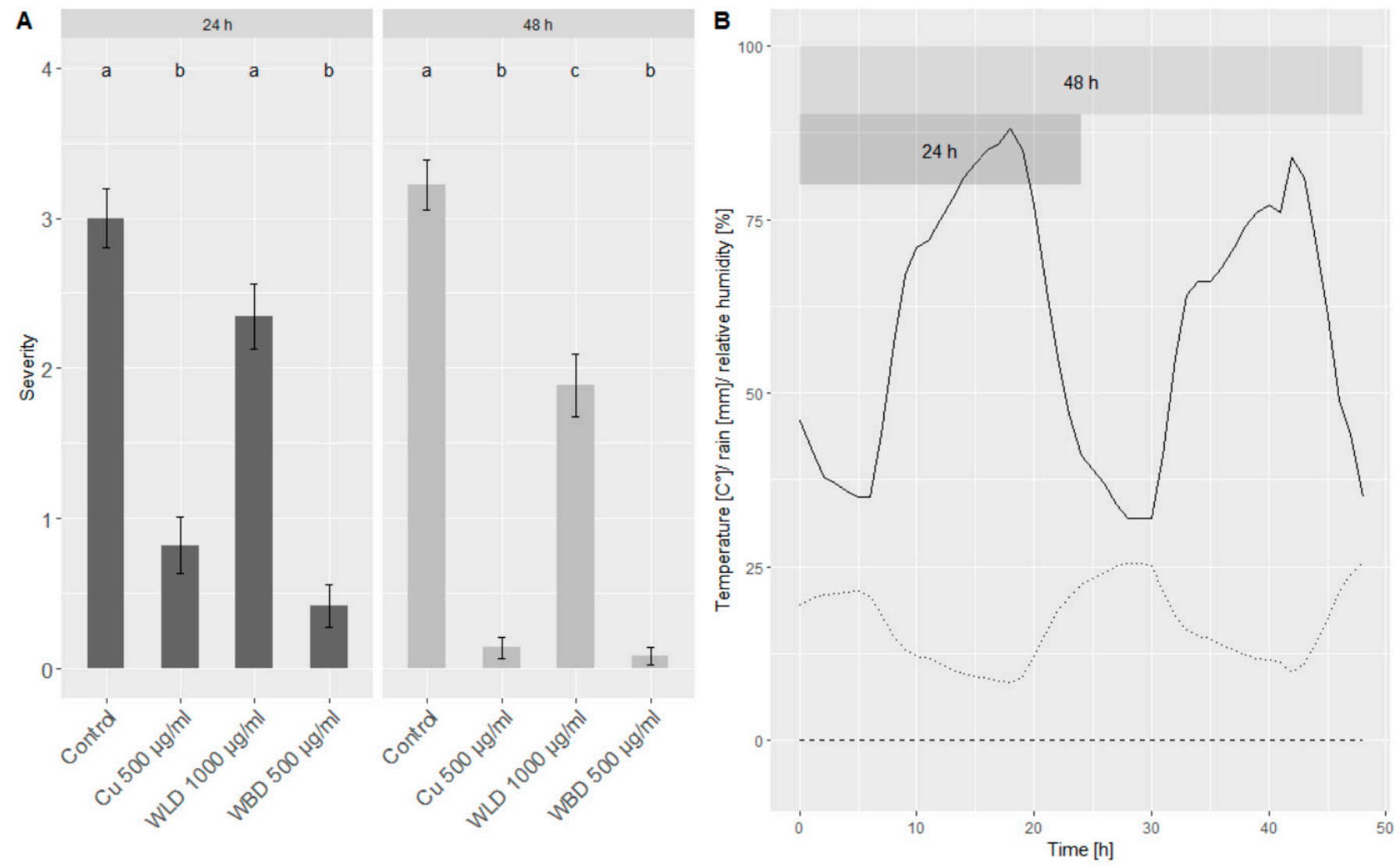

Figure 3. (A) Merged (cv. 'Müller-Thurgau' and 'Pinot Noir') results of the leaf disc assay conducted with seedling plants under semi-controlled conditions. Shown is the infection severity of leaf discs treated either with water (control), Cu-fungicide $500 \mu \mathrm{g} / \mathrm{mL}$, WLD $1000 \mu \mathrm{g} / \mathrm{mL}$ or WBD $500 \mu \mathrm{g} / \mathrm{mL}$ : (0) no sporulation, (1) minimal sporulation, (2) low sporulation, (3) medium sporulation, (4) full sporulation. Welch's anova and Games-Howell test for multiple comparison: Different letters indicate significant $(p<0.05 ; n=72)$ differences between groups. (B) Weather conditions during the time of the experiment, when seedlings were placed in the field: Dashed line = rain, dotted line = temperature, solid line $=$ relative humidity.

\subsection{Field Trials}

In the season 2021 a field trial in two vineyards (cv. 'Riesling' and 'Dornfelder') was conducted to test the efficacy of the WU extracts under field conditions. The season 2021 was characterized by multiple and partially heavy rainfalls (Figure 4); from May to August, 57 out of 123 days showed rainfall, with a total amount of $411.8 \mathrm{~mm}$ and a mean precipitation of $7.2 \mathrm{~mm}$ per rain day.

Due to massive and frequent rain events, DM primary infection and consequently multiple secondary infections occurred in the trial fields (Figure 5). In the untreated control blocks, the infection rate on leaves reached $100 \%$ in the last monitoring (at BBCH 79) with a severity of around 55\%. This was true for both trial fields, 'Dornfelder' and 'Riesling'. Also on inflorescences, the infection rate in both fields was $100 \%$ in the last assessment, with a severity of $91 \%$ and $97 \%$, respectively. 
50 -

$40-$

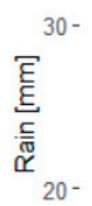

$10-$
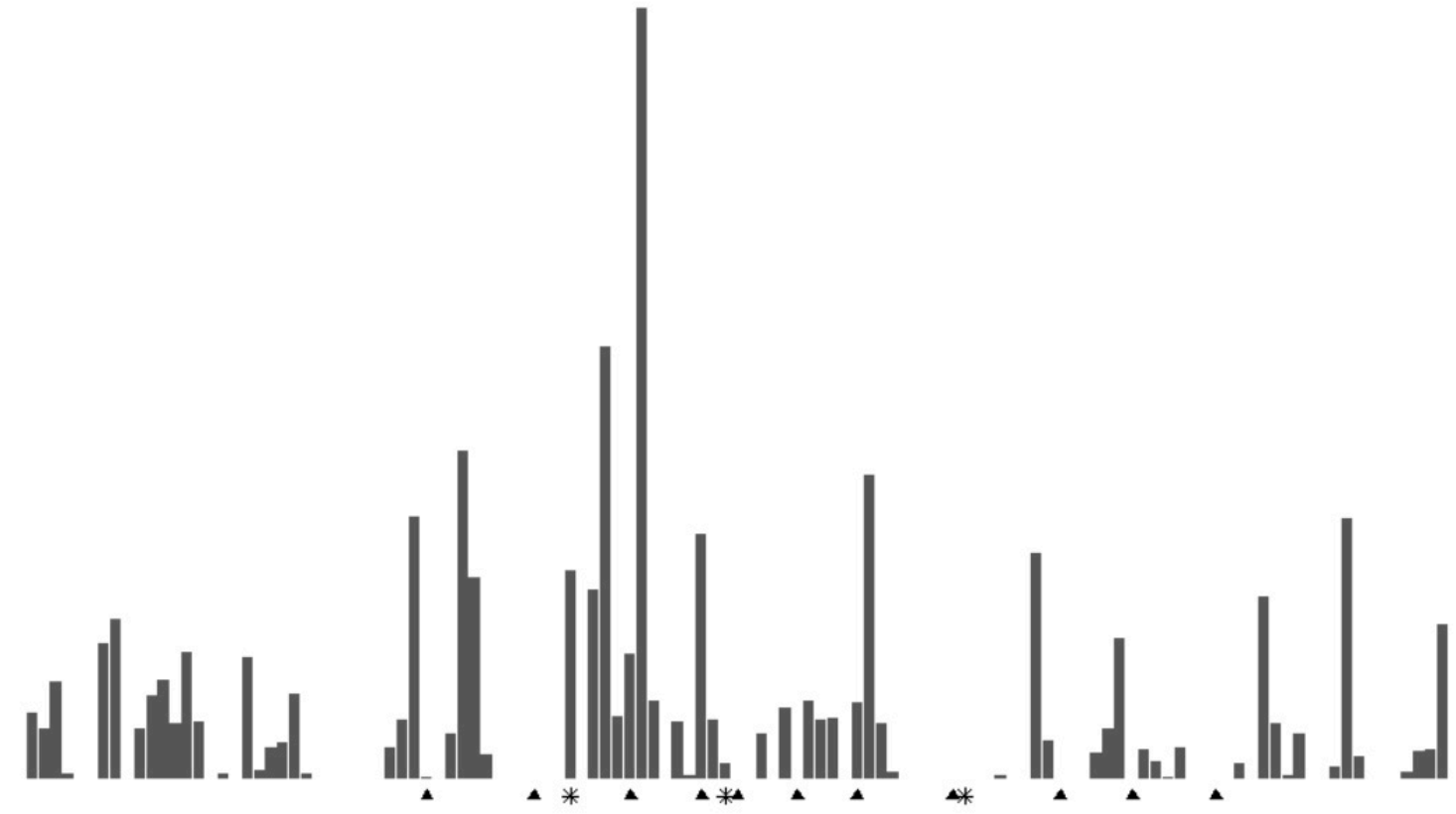

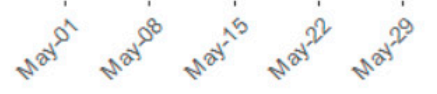

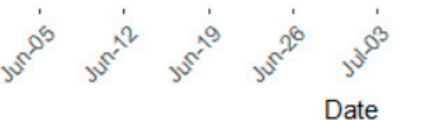

Figure 4. Daily rainfall (mm) during the season 2021 from May to August at the Julius Kühn-Institute facilities in Siebeldingen, Rhineland-Palatinate, Germany. Triangles indicate date of plant protection application $\left(\sum=11\right)$. Asterisks indicate date of DM assessment $\left(\sum=3\right)$.

A

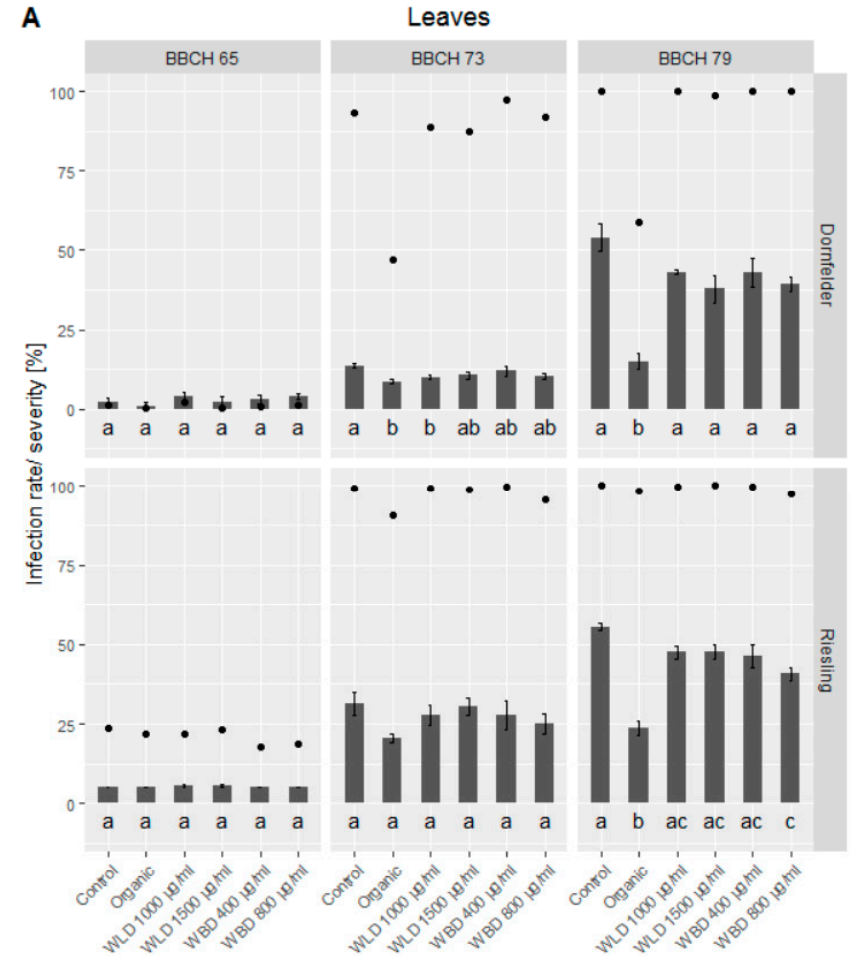

B

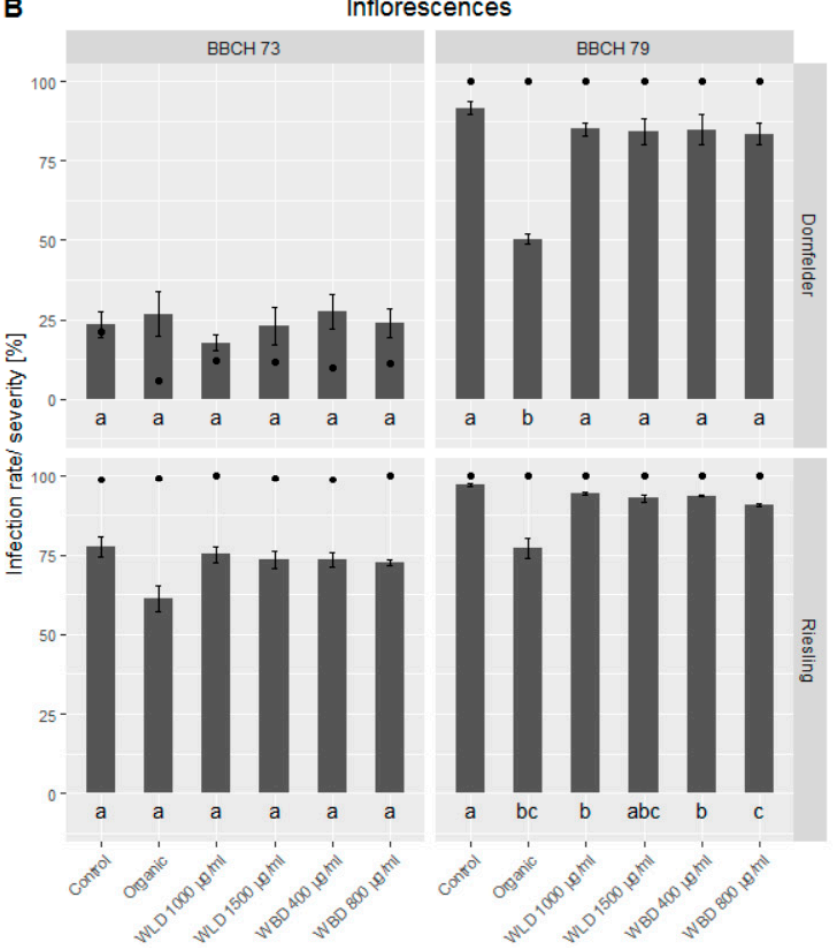

Figure 5. Mean DM infection rate (dots) and severity (bars) in the two trial fields, 'Dornfelder' and 'Riesling'. (A) Leaves were assessed on three phenological stages $(\mathrm{BBCH} 65, \mathrm{BBCH} 73, \mathrm{BBCH} 79)$ and (B) inflorescences on two phenological stages (BBCH 73, BBCH 79). Welch's anova and Games-Howell test for multiple comparison: Different letters indicate significant differences in mean infection severity; $p<0.05$; 'Dornfelder': $n=5$, 'Riesling': $n=4$. 
Regarding leaf infection, on the first assessment (full flowering, BBCH 65), in both vineyards no differences in efficacy (based on infection severity) could be found between the different treatments (Table 1); however, DM infection severity (1.0-5.5\%) in general was low at this time. Two weeks later, when berries had groat-size $(\mathrm{BBCH} 73)$ and the infection rate and severity increased, a slight protective effect of the organic treatment could be noticed with an efficacy of 36.3\% for 'Dornfelder' and 33.3\% for 'Riesling'. Among the WU extracts, WLD $1000 \mu \mathrm{g} / \mathrm{mL}$ reached the highest efficacy at this stage with $26.6 \%$. When majority of the berries were touching (BBCH 79), the efficacy of the organic treatment increased up to $71.7 \%$ in the 'Dornfelder' field and $57.2 \%$ in the 'Riesling' field. Here, the efficacy of the WU extracts varied between 13.8\% (WLD $1500 \mu \mathrm{g} / \mathrm{mL}$, 'Riesling') and 30.3\% (WLD $1400 \mu \mathrm{g} / \mathrm{mL}$, 'Dornfelder').

Table 1. Efficacy (\%) of the WU extracts based on the assessment data (only infection severity) from the trial field experiment conducted in 2021 in two vineyards ('Dornfelder' and 'Riesling'). Shown is the mean efficacy ( \pm sd) on three and two, respectively, different phenological stages of each tested treatment: Organic, WLD $1000 \mu \mathrm{g} / \mathrm{mL}, \mathrm{WLD} 1500 \mu \mathrm{g} / \mathrm{mL}$, WBD $400 \mu \mathrm{g} / \mathrm{mL}$ and WBD $800 \mu \mathrm{g} / \mathrm{mL}$.

\begin{tabular}{cccccccc}
\hline & & & Leaf & & \multicolumn{2}{c}{ Inflorescences } \\
\hline \multirow{2}{*}{ Organic } & & $n$ & BBCH 65 & BBCH73 & BBCH 79 & BBCH 73 & BBCH 79 \\
& 'Dornfelder' & 5 & $40.0 \pm 54.8$ & $36.3 \pm 12.5$ & $71.7 \pm 11.4$ & $-33.7 \pm 102.5$ & $45.2 \pm 2.2$ \\
& 'Riesling' & 4 & $0.0 \pm 0.0$ & $33.3 \pm 10.1$ & $57.2 \pm 8.4$ & $20.0 \pm 17.4$ & $20.6 \pm 6.5$ \\
\hline \multirow{2}{*}{ WLD $1000 \mu \mathrm{g} / \mathrm{mL}$} & 'Dornfelder' & 5 & $16.0 \pm 47.7$ & $26.6 \pm 4.3$ & $18.0 \pm 16.8$ & $18.1 \pm 34.0$ & $7.0 \pm 7.8$ \\
& 'Riesling' & 4 & $-10.0 \pm 11.5$ & $6.8 \pm 34.2$ & $14.2 \pm 9.4$ & $2.3 \pm 11.9$ & $2.8 \pm 0.5$ \\
\hline \multirow{2}{*}{ WLD $1500 \mu \mathrm{g} / \mathrm{mL}$} & 'Dornfelder' & 5 & $40.0 \pm 54.8$ & $21.9 \pm 14.9$ & $30.3 \pm 14.4$ & $-3.4 \pm 65.2$ & $8.4 \pm 8.1$ \\
& 'Riesling' & 4 & $-10.0 \pm 11.5$ & $-1.0 \pm 28.0$ & $13.8 \pm 9.4$ & $4.6 \pm 11.6$ & $4.4 \pm 2.0$ \\
\hline \multirow{2}{*}{ WBD $400 \mu \mathrm{g} / \mathrm{mL}$} & 'Dornfelder' & 5 & $3.3 \pm 7.5$ & $9.6 \pm 33.9$ & $19.1 \pm 22.1$ & $-23.8 \pm 66.4$ & $7.6 \pm 7.7$ \\
& 'Riesling' & 4 & $0.0 \pm 0.0$ & $8.2 \pm 35.9$ & $16.7 \pm 13.1$ & $4.2 \pm 14.6$ & $3.6 \pm 1.0$ \\
\hline \multirow{2}{*}{ WBD $800 \mu \mathrm{g} / \mathrm{mL}$} & 'Dornfelder' & 5 & $3.3 \pm 7.5$ & $21.9 \pm 20.9$ & $25.2 \pm 18.3$ & $-3.1 \pm 29.1$ & $9.0 \pm 5.2$ \\
& 'Riesling' & 4 & $0.0 \pm 0.0$ & $17.9 \pm 28.0$ & $26.5 \pm 7.0$ & $5.5 \pm 10.1$ & $6.4 \pm 0.5$ \\
\hline
\end{tabular}

In the first assessment of the inflorescences $(\mathrm{BBCH} 73)$ the infection rate and severity differed between the two vineyards and so did the efficacy. No differences were found in the low infected 'Dornfelder' field between the five treatments, since infection severity was more or less the same for all treatments (17.8-27.4\%). In the 'Riesling' field, the infection rate was almost around $100 \%$ in all treatments and according to the infection severity, the organic treatment revealed an efficacy of $20 \%$ while the WU extracts only showed an efficacy between $2.3 \%$ and $5.5 \%$ (Table 1). At BBCH 79 the infection rate of the inflorescences was $100 \%$ in all treatments of the 'Dornfelder' field. Here, the organic treatment had an efficacy of $45.2 \%$ and the WU extracts showed an efficacy between $7.0 \%$ and $9.0 \%$. In the already highly infested 'Riesling' field, the infection severity of the inflorescences slightly increased, from $\mathrm{BBCH} 73$ to $\mathrm{BBCH} 79$, but the efficacy of the five treatments did not change over time; the organic treatment yielded $20.6 \%$ and the WU extracts reached $2.8 \%$ to $6.4 \%$.

\section{Discussion}

Already decades ago, it has been shown that extracts made of Warburgia spp. are highly concentrated in compounds with antifungal activities [31,40]. The phytochemicals with the highest contribution to the antifungal properties of WU extracts belong to the group of sesquiterpenes; polygodial, warburganal and muzigadial $[33,40]$. In microtiter assays, their ability to inhibit the fungal growth could be demonstrated for Candida utilis (polygodial, $\mathrm{MIC}_{50}=1.56 \mu \mathrm{g} / \mathrm{mL} ;$ warburganal $\mathrm{MIC}_{50}=3.13 \mu \mathrm{g} / \mathrm{mL}$; muzigadial, $\mathrm{MIC}_{50}=3.13 \mu \mathrm{g} / \mathrm{mL}$ ) and Saccharomyces cerevisiae (polygodial, $\mathrm{MIC}_{50}=0.78 \mu \mathrm{g} / \mathrm{mL}$; warburganal $\mathrm{MIC}_{50}=3.13 \mu \mathrm{g} / \mathrm{mL}$; muzigadial, $\mathrm{MIC}_{50}=1.56 \mu \mathrm{g} / \mathrm{mL}$ ), among others [50]. Muzigadial could also inhibit growth of the filamentous fungi Fusarium oxysporum $\left(\mathrm{MIC}_{100}=50 \mu \mathrm{g} / \mathrm{mL}\right.$ ) and Aspergillus niger 
$\left(\mathrm{MIC}_{100}=5 \mu \mathrm{g} / \mathrm{mL} ; 42\right)$. With Warburgia salutaris bark extract, Kuglerova et al. [41], in a microtiter assay, determined an $\mathrm{MIC}_{50}$ of $256 \mu \mathrm{g} / \mathrm{mL}$ for Candida albicans. The microtiter assay as performed in our study revealed an $\mathrm{MIC}_{100}$ (sporangia germination rate) for P. viticola of appr. $500 \mu \mathrm{g} / \mathrm{mL}$ for the WU leaf extract and appr. $5 \mu \mathrm{g} / \mathrm{mL}$ for the bark extract. For comparison, other plant extracts used against $P$. viticola expressed an $\mathrm{MIC}_{100}$ of $35 \mu \mathrm{g} / \mathrm{mL}$ (Verbesina lanata, 28), $24 \mu \mathrm{g} / \mathrm{mL}$ (Juncus effusus, 26) and $12 \mu \mathrm{g} / \mathrm{mL}$ (Magnolia officinalis, 29). The difference between the two $\mathrm{MIC}_{100}$ values by a factor of 100 indicates a higher concentration of antifungal active compounds in the bark of WU trees. With this in agreement, Abuto et al. [45], who tested WU leaf and bark extracts against Staphylococcus aureus and C. albicans, and in addition compared the phytochemical profile of the two plant parts, showed that bark extracts display a larger concentration of antimicrobial compounds than leaf extracts.

In the past, the antifungal properties of WU extracts were only proven against ascomycetes [31,33]. To our knowledge, our study is the first that the inhibitory activity of WU extracts could also be demonstrated against an oomycete. So far, inhibitory effects of crude WU extracts were only shown against fungi (Candida albicans, Fusarium spp., Penicillium spp.), bacteria (Staphylococcus spp., Bacillus spp., Shigella boydii, Escherichia coli, Enterococcus faecalis, Mycobacterium spp., Neiserria gonorrhoea) and Plasmodium spp. [34,41,43,44,51-54]. Our results together with the above studies indicate that WU extracts in fact exhibit a much broader antimicrobial activity and antifungal activity could also be expected against other fungal phytopathogens in viticulture, for example Erysiphe necator (Powdery Mildew) or Botrytis cinerea (Grey Mould).

Sprayed on grapevine leaf discs, WU leaf extracts suppressed DM infection at $500 \mu \mathrm{g} / \mathrm{mL}$, but efficacy was closely linked to the time point of infection. No long-term protection was noted at this concentration. On the other hand, WU bark extracts could protect the leaf discs from immediate infection at $50 \mu \mathrm{g} / \mathrm{mL}$. At $500 \mu \mathrm{g} / \mathrm{mL}$, the bark extract could even suppress DM development for up to $48 \mathrm{~h}$. The same effect could be seen under semi-controlled conditions, when seedling plants were exposed to field conditions for 24 and $48 \mathrm{~h}$, respectively, after treatment. Here, WLD with $1000 \mu \mathrm{g} / \mathrm{mL}$ also expressed protective abilities against DM; efficacy, however, was limited. In a leaf disc bioassay, extracts based on Pinus pinaster knot at $500 \mu \mathrm{g} / \mathrm{mL}$ could fully suppress DM infection [55]. Using Juncus effusus medulla extract and Magnolia officinalis bark extracts, Thuering and colleagues [26,29] could reduce DM infection on grapevine seedlings with an efficacy of $>90 \%(256 \mu \mathrm{g} / \mathrm{mL})$ and $97 \%(1000 \mu \mathrm{g} / \mathrm{mL})$, respectively. In general, extracts made of tree bark seem to be highly effective against DM. Mulholland et al. [56] tested bark extract from eight important northern forestry species on grapevine seedlings and all of them expressed significant inhibitory activity (between 50\% and 98\% efficacy) against $\mathrm{DM}$ at $1000 \mu \mathrm{g} / \mathrm{mL}$. Furthermore, the authors identified several compounds with high efficacies against DM, namely larixyl acetate, larixol, lariciresinol, lariciresinol acetate and 15-hydroxydehydroabietic acid.

Although promising results were achieved in our laboratory and greenhouse tests, the efficacy of the WU extracts was distinctly reduced under field conditions. Among the tested conditions, the highest efficacy (30.3\%) was reached in the 'Dornfelder' field at BBCH 79 by spraying leaves with WLD $1500 \mu \mathrm{g} / \mathrm{mL}$. In contrast, in the 'Riesling' trial this treatment had the lowest efficacy (13.8\%) among the WU extracts also at BBCH 79. For WBD $800 \mu \mathrm{g} / \mathrm{mL}$, the leaf assessment resulted in similar efficacies for both trials, $25.2 \%$ ('Dornfelder') and 26.5\% ('Riesling') at BBCH 79. For the inflorescences efficacy data of all tested WU extracts were beneath $10 \%$ at BBCH 79. Especially the low efficacies of the bark extracts at $800 \mu \mathrm{g} / \mathrm{mL}$ were unexpected, because in the preliminary tests $500 \mu \mathrm{g} / \mathrm{mL}$ WBD could effectively suppress DM infection on leaf discs and seedlings for up to $48 \mathrm{~h}$. Basically, discrepancies in inhibition efficacy between controlled and field conditions are well known and might be due to several factors. Bark extract of M. officinalis, for instance, showed efficacy of $97 \%$ when used on grapevine seedlings under controlled conditions [29], while under field conditions the extract reached only $26 \%$ efficacy. Furthermore, Dagostin 
and colleagues [24] reported an efficacy between $79.9 \%$ and $95.8 \%$ for S. officinalis extracts when treating seedlings in the greenhouse. In field trials, however, the efficacy decreased to $17.5 \%$ in the first trial year and to $20.0 \%$ in the second year. One main reason for the efficacy decline under field conditions is probably rainfall, which washes off the extracts from the plant surface. In a simulated rain experiment $(30 \mathrm{~mm} / \mathrm{h})$, the efficacy of a S. officinalis extract declined by $50 \%$ when precipitation was $50 \mathrm{~mm}$ [24]. When exposed to $10 \mathrm{~mm}$, the efficacy already dropped from $80 \%$ to $50 \%$. In the same experiment with a PPP based on Cu-hydroxide, the efficacy only marginally decreased from $80 \%$ to $70 \%$, demonstrating a distinctly higher rain resistance. This would explain why the efficacy of the $\mathrm{Cu}$-based organic treatment in our field trials was higher than for the WU extracts. One possible solution to improve rain resistance could be the use of proper formulations, like encapsulation $[57,58]$. Another option to improve the efficacy of the extracts in the field could be the addition of proper adjuvants, like silicon surfactants, that increase coverage and persistence on the plant [59-61]. Not only rain resistance, but also UV-stability of the WU extracts require further investigation to determine a suitable formulation that can improve the efficacy. Increasing the concentration of the antimicrobial compounds in the extract could be another way for a higher effectiveness. This could be reached either by choosing novel, innovative extraction methods or by certain cultivation practices that lead to higher synthesis of secondary metabolites in the leaves/bark [62-64].

In conclusion, under controlled and semi-controlled conditions low concentrations of leaves $(1000 \mu \mathrm{g} / \mathrm{mL})$ and bark $(500 \mu / \mathrm{mL})$ extracts of the African tree $W$. ugandensis could effectively prevent DM infection on leaf discs and seedlings, respectively. However, under field conditions the protective efficacy of the extracts against DM decreased significantly. Nevertheless, WU extracts may represent a suitable alternative to $\mathrm{Cu}$-based fungicides in being nontoxic, sustainable and cost-effective. Future emphasis shall be on finding the particular formulations for the extracts in order to increase the rain resistance and thus the efficacy under true field conditions, including conditions of high infection pressure.

\section{Material and Methods}

\subsection{Plant Material E Extraction}

The plant material (leaves and barks) of Warburgia ugandensis was obtained from a medicinal plant farm in Pakwach district, Western Uganda. Exports of the plant material for research purposes was reported to and approved by the Ugandan authorities. For bark, 5-8 cm wide strips of bark were carefully peeled off the sapwood lengthwise. This procedure prevents the tree from dying. The leaves were harvested by pruning the WU shrubs, analogous to a hedge trimming. Both leaves and thin twigs were cut off. Then, both bark and leaves were washed and afterwards dried in the shade for about 7 days. When the moisture content was below $12 \%$, the leaves were carefully stripped from the twigs and packed in air-permeable bags. They were stored in a dark room at a humidity below 15\% to prevent rot formation. Five $\mathrm{kg}$ of fresh leaves yielded about $1 \mathrm{~kg}$ of dried leaves.

The plants for the WU plantation were obtained from a nursery of the state-owned National Forestry Resources Research Institute (NaFORRI) in Kifu (Uganda). The seeds were collected in the wild, exclusively by experts authorized for this purpose.

For the preparation of the extracts, both leaves and bark were ground to a particle size of $50 \mu \mathrm{m}$ (IKA ${ }^{\circledR}$ M20 Universal Mill, VWR International GmbH, Darmstadt, Germany). In each case, $100 \mathrm{~g}$ of the pulverized leaves or bark was mixed with $900 \mathrm{~mL}$ dichloromethane (Roth ${ }^{\circledR}$, Karlsruhe, Germany). The extraction mixtures were incubated for $72 \mathrm{~h}$ with gentle shaking (100 rpm). Afterwards, the extraction mixtures were filtered and concentrated with a rotary evaporator (Rotavapor ${ }^{\circledR}$ RE 111, Büchi Labortechnik GmbH, Essen, Germany) at a temperature of $50{ }^{\circ} \mathrm{C}$ until all dichloromethane was evaporated. Extract yields were 12-14\% $(w / w)$ for leaves and $8 \%(w / w)$ for barks, based on the raw plant material mass input. 


\subsection{Pathogen Cultivation}

Plasmopara viticola was cultivated on grapevine (Vitis vinifera) seedlings cv. 'MüllerThurgau' in a climate chamber. The climate conditions were $22{ }^{\circ} \mathrm{C}$ and $70 \%$ relative humidity with a $14 / 10 \mathrm{~h}$ day/night rhythm. Plants with $6-8$ leaves were inoculated by spraying a sporangia suspension $(20,000-30,000$ sporangia $/ \mathrm{mL})$ on the abaxial site of the leaves. Subsequently, the whole plants were moistened with water, also by spraying, and packed in plastic bags. The plants were incubated for $24 \mathrm{~h}$ in the climate chamber before the plastic backs were removed. After, the plants were incubated 5-7 days in the climate chamber until oil spots were visible. Next, the adaxial site of the leaves were moistened with water and the plants were packed again in plastic bags. A total of $24 \mathrm{~h}$ later, the bags were carefully removed and sporangia were noticed on the abaxial site of the leaves. The cultivation process of $P$. viticola was repeated weekly to obtain fresh sporangia for the experiments.

\subsection{In Vitro Bioassays}

Sets of 96-well plates were used for the in vitro bioassays to determine the minimal inhibitory concentration $50\left(\mathrm{MIC}_{50}\right)$ and $100\left(\mathrm{MIC}_{100}\right)$ of the WU extracts against P. viticola. All extracts were dissolved in DMSO (Carl Roth GmbH, Karlsruhe, Germany) to achieve a stock concentration of $60 \mathrm{mg} / \mathrm{mL}$. After this, a serial of nine dilutions were set up with $\mathrm{H}_{2} \mathrm{O}_{\mathrm{dd}}$ to reach the following end concentrations in the wells: $0.05,0.1,0.5,1,5,10,50$, $100,500 \mu \mathrm{g} / \mathrm{mL}$. From infected leaves, fresh sporangia were rinsed off with $\mathrm{H}_{2} \mathrm{O}_{\mathrm{dd}}$ and the suspension was adjusted to 20,000-30,000 sporangia/mL. In each well, $100 \mu \mathrm{L}$ of the diluted extract was mixed with $100 \mu \mathrm{L}$ of the sporangia suspension and the 96-well plate was incubated at room temperature on the bench. As a negative control, $\mathrm{H}_{2} \mathrm{O}_{\mathrm{dd}}$ with DMSO (same amount as for the extract dilutions) was used and a $\mathrm{Cu}$-based fungicide (active agent: $537 \mathrm{~g} / \mathrm{kg} \mathrm{Cu}$ hydroxide $=350 \mathrm{~g} / \mathrm{kg} \mathrm{Cu}^{2+}$; Funguran ${ }^{\circledR}$ progress, Biofa AG, Münsingen, Germany) as the comparative PPP. In one experiment, each treatment and concentration, respectively, had four replicates and the experiment was repeated four times.

The zoospore behavior and the sporangia germination rate were chosen to quantify the inhibitory effect of the tested products. The former was observed $1 \mathrm{~h}$ after incubation and rated according to three categories: ( 0 ) normal zoospore motion; $(-1)$ no or unusual zoospore motion; $(-2)$ no zoospore release. The sporangia germination rate was calculated $24 \mathrm{~h}$ after incubation by checking 50 sporangia per well for zoospore release.

\subsection{In Vivo Bioassays}

Leaf discs from greenhouse seedlings cv. 'Müller-Thurgau' and 'Pinot noir' were used for in vivo bioassays. Leaves were detached from the plants and washed with $\mathrm{H}_{2} \mathrm{O}_{\mathrm{dd}}$. For each cultivar, the required amount of leaf discs for one experiment was cut from leaves with a cork borer ( $15 \mathrm{~mm}$ diameter), collected in a box and mixed. Per treatment variant, 12 random leaf discs, six from each cultivar, were put in a petri dish with wet filter paper, the abaxial site up.

As descripted above for the in vitro assays, three dilutions for each extract were made: $5,50,500 \mu \mathrm{g} / \mathrm{mL}$. The extracts were sprayed horizontally on the leaf discs by using an application chamber (SprayLab Epilogic, Schachtner Gerätetechnik, Ludwigsburg, Germany) with following settings: $32 \mathrm{~cm}$ distance from leaf discs to nozzle, 3.0 bar pressure, $2.5 \mathrm{~km} / \mathrm{h}$ spraying device pace, $300 \mathrm{~L} / \mathrm{ha}$ application rate. Control leaf discs were sprayed with $\mathrm{H}_{2} \mathrm{O}_{\text {dd }}$ containing DMSO (the same amount as for the extract dilutions) and for comparison, a Cu-based fungicide (Funguran ${ }^{\circledR}$ progress, Biofa GmbH, Münsigen, Germany) with the same concentrations as the extracts was applied. After application of each treatment, the spraying device was cleaned with $\mathrm{H}_{2} \mathrm{O}_{\mathrm{dd}}$. The sprayed leaf discs were arranged on a $0.8 \%$ $\mathrm{H}_{2} \mathrm{O}_{\text {dd }}$-agar plate (Agar-Agar, Carl Roth, Karlsruhe, Germany) with abaxial site up and inoculated with a $70 \mu \mathrm{L}$ drop of a sporangia suspension $(20,000-30,000$ sporangia/mL). Subsequently, the agar plates with the inoculated leaf discs were incubated in the climate chamber at the same conditions as for the pathogen cultivation. A total of $24 \mathrm{~h}$ after inocu- 
lation, the drops were removed from the leaf discs with a vacuum device (Mini-Vac, Axon Lab AG, Stuttgart, Germany). Then, plates were put back to the climate chamber for further incubation. The full sporangiophore formation was noticed about 10 days after inoculation. At this time, the infection severity on the leaf discs was evaluated based on five severity categories: (0) no sporulation; (1) minimal sporulation; (2) low sporulation; (3) medium sporulation (4) full sporulation (Figure 6). In order to investigate the temporal protective effect of the extracts, the sprayed leaf discs were inoculated with sporangia either directly after the treatment $(0 \mathrm{~h}), 24 \mathrm{~h}$ after the treatment or $48 \mathrm{~h}$ after the treatment. For each time point, the experiment was repeated four times. Statistical analysis of the data was done with RStudio [65]. With Welch's anova and Games-Howell test for multiple comparison, a non-parametric approach was chosen for statistical analysis since the obtained data (infection severity) were not normally distributed and showed heteroscedasticity.
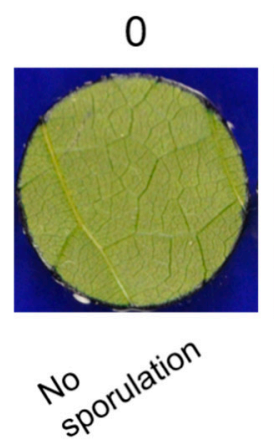

1
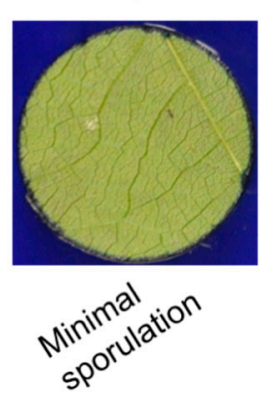

2
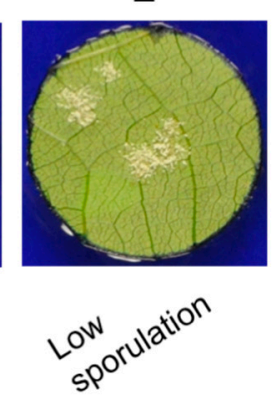

3
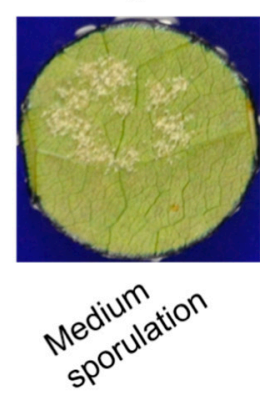

4
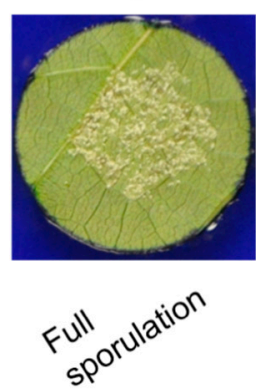

Figure 6. Severity categories used in this work to evaluate the degree of infection on grapevine leaf discs.

\subsection{Tests under Semi-Controlled Conditions}

Greenhouse seedlings cv. 'Müller-Thurgau' and 'Pinot noir' were used to test the efficacy of the extracts under field conditions. The whole plants (10 to 15 leaves) were treated in the SprayLab application chamber using a tunnel spraying device with one nozzle on each side and following settings: $55 \mathrm{~cm}$ distance from nozzle to nozzle, $5.0 \mathrm{bar}$ pressure, $1.0 \mathrm{~km} / \mathrm{h}$ spraying device pace, $400 \mathrm{~L} / \mathrm{ha}$ application rate. The treatments were as follows: Control ( $\mathrm{H}_{2} \mathrm{O}_{\mathrm{dd}}$ with DMSO), $\mathrm{Cu}$-fungicide (Funguran ${ }^{\circledR}$ progress, Biofa GmbH, Münsigen, Germany) $500 \mu \mathrm{g} / \mathrm{mL}$, WBD $500 \mu \mathrm{g} / \mathrm{mL}$, WLD $1000 \mu \mathrm{g} / \mathrm{mL}$. For each treatment, six seedlings cv. 'Müller-Thurgau' and six seedlings cv. 'Pinot noir' were taken. After the treatment, seedlings were put outside in front of the greenhouse. A total of $24 \mathrm{~h}$ later, half of the seedlings were brought to the lab for inoculation with $P$. viticola, the other half after $48 \mathrm{~h}$. From each plant, four leaves were randomly removed and from each leaf three leaf discs were cut. In total, 72 leaf discs per treatment and time point ( 24 and $48 \mathrm{~h}$ ) were prepared, inoculated and evaluated as described in the Section 4.4 In Vivo Bioassays. Here as well, Welch's anova and Games-Howell test for multiple comparison were chosen for statistical analysis.

\subsection{Field Trials}

Two vineyards were selected for the field trials in 2021. Both were in close vicinity to the Julius Kühn-Institute facilities in Siebeldingen, Rhineland-Palatinate, Germany. One vineyard was planted with the white grapevine cultivar 'Riesling' $\left(49^{\circ} 13^{\prime} 44.6^{\prime \prime} \mathrm{N} 8^{\circ} 00^{\prime} 25.6^{\prime \prime} \mathrm{E}\right)$. The second vineyard was planted with the red cultivar 'Dornfelder' $\left(49^{\circ} 12^{\prime} 55.1^{\prime \prime} \mathrm{N} 8^{\circ} 02^{\prime} 08.9^{\prime \prime} \mathrm{E}\right)$. Both vineyards were established on loamy soil and the plants were trained in vertical shoot positioning.

A randomized block design was chosen for the trial and the experiment was conducted based on the EPPO guidelines for P. viticola (PP 1/31(3)). The 'Riesling' vineyard consisted of 24 rows with 25 plants per row. For each treatment, four rows were randomly picked resulting in 100 plants per PPP. The 'Dornfelder' vineyard consisted of 10 rows with 
60 plants per row. Here, each of the rows were divided into three blocks and for each treatment, five blocks were randomly picked resulting also in 100 plants per PPP.

Six treatments were set up for the field trial: Untreated control, organic treatment, WBD $400 \mu \mathrm{g} / \mathrm{mL}$, WBD $800 \mu \mathrm{g} / \mathrm{mL}$, WLD $1000 \mu \mathrm{g} / \mathrm{mL}$, WLD $1500 \mu \mathrm{g} / \mathrm{mL}$. The vines in the untreated control received no protection spraying. For the organic treatment, a mixture of Cu-based PPP (2 g/L, Funguran ${ }^{\circledR}$ progress) against DM plus net sulfur $(9 \mathrm{~g} / \mathrm{L}$, Stulln, Biofa AG, Münsingen, Germany) against Powdery Mildew (Erysiphe necator) was used. The bark and leaf extracts were dissolved in DMSO to achieve a stock concentration of $250 \mathrm{mg} / \mathrm{mL}$ and with tap water the final spraying concentrations were prepared.

During the season, eleven plant protection applications took place using a spraying device for tractors (parcel sprayer, Schachtner Gerätetechnik, Ludwigsburg, Germany) carrying six pressure tanks with $25 \mathrm{~L}$ volume (Figure 2). Spraying took place in a tunnel with five nozzles on each side. While spraying, the tractor had a constant speed of $4 \mathrm{~km} / \mathrm{h}$ resulting in a spraying amount of about $400 \mathrm{~L} / \mathrm{ha}$.

DM assessments were made on three dates during the season 2021: 18 June $(\mathrm{BBCH}$ 65, full flowering), 1 July (BBCH 73, berries groat-sized) and 21 July (BBCH 79, majority of berries touching). On the first date, only leaves were assessed, and on the second and third, leaves and inflorescences. In each treatment block, 100 randomly picked leaves/inflorescences were evaluated for DM infection. The infection rate (percentage of infected leaves/inflorescences) and severity (percentage of infected leaf/inflorescences area) was determined. Furthermore, the efficacies of the treatments were calculated according to Abbott [66]: $\left[1-\left(\mathrm{A} \times \mathrm{B}^{-1}\right)\right] \times 100$; with ' $\mathrm{A}$ ' as the infection severity of the treatment block and ' $\mathrm{B}$ ' as the infection severity of the control block.

Statistical analysis was done using the infection severity data and the program $\mathrm{R}$. The grouped data set (by means of assessed plant part, cultivar, assessment date) were not normally distributed and mainly showed homoscedasticity. However, since the sample size was low ('Dornfelder': $n=5$; 'Riesling': $n=4$ ) Welch's anova and Games-Howell test for multiple comparison were chosen to find significant differences between the treatment groups.

\subsection{Weather Data}

Because climatic conditions, especially rainfall, is an important driving force in the epidemiology of P. viticola, we collected data from a weather station close to the Julius KühnInstitute facilities $\left(49^{\circ} 12^{\prime} 59.4^{\prime \prime} \mathrm{N} 8^{\circ} 02^{\prime} 52.6^{\prime \prime} \mathrm{E}\right)$. The station is run by the DLR RhinelandPalatinate (www.dlr.rlp.de, accessed on 1 December 2021).

Author Contributions: Conceptualization, C.K., R.A.-A., A.S. and M.F.; methodology, C.K., R.A.-A., A.S. and M.F.; software, C.K.; validation, C.K.; formal analysis, C.K.; investigation, C.K.; resources, C.K., R.A.-A., A.S. and M.F.; data curation, C.K.; writing—original draft preparation, C.K.; writingreview and editing, C.K., R.A.-A., A.S. and M.F.; visualization, C.K.; supervision, A.S. and M.F.; project administration, A.S. and M.F.; funding acquisition, A.S. and M.F. All authors have read and agreed to the published version of the manuscript.

Funding: We gratefully acknowledge the financial support of the Federal Office for Agriculture and Food (BLE) and the Federal Ministry of Food and Agriculture (BMEL). This work was conducted in the framework of the project VinoProtect (FKZ 2818OE043).

Institutional Review Board Statement: Not applicable.

Informed Consent Statement: Not applicable.

Data Availability Statement: Data collected in this study are available from the corresponding author upon request.

Conflicts of Interest: The authors declare no conflict of interest. 


\section{References}

1. Farlow, W.G. The American grape mildew. Bussy Inst. Bull. 1876, 1, 423.

2. Gessler, C.; Pertot, I.; Perazzolli, M. Plasmopara viticola: A review of knowledge on Downy Mildew of grapevine and effective disease management. Phytopathol. Mediterr. 2011, 50, 3-44.

3. Millardet, A. Traitement du mildiou par le mélange de sulphate de cuivre et chaux. J. Agric. Pract. 1885, 49, 707-710.

4. Richardson, H.W. Handbook of Copper Compounds and Applications: Copper Fungicides/Bactericides; Dekker: New York, NY, USA, 1997; ISBN 9780824789985.

5. Rusjan, D.; Strlič, M.; Pucko, D.; Korošec-Koruza, Z. Copper accumulation regarding the soil characteristics in Sub-Mediterranean vineyards of Slovenia. Geoderma 2007, 141, 111-118. [CrossRef]

6. La Torre, A.; Iovino, V.; Caradonia, F. Copper in plant protection: Current situation and prospects. Phytopathol. Mediterr. 2018, 57, 201-236.

7. Flamming, C.A.; Trevors, J.T. Copper toxicity and chemistry in the environment: A review. Water Air Soil Pollut. 1989, 44, 143-158. [CrossRef]

8. $\quad$ Eijsackers, H.; Beneke, P.; Maboeta, M.; Louw, J.P.E.; Reinecke, A.J. The implications of copper fungicide usage in vineyards for earthworm activity and resulting sustainable soil quality. Ecotoxicol. Environ. Saf. 2005, 62, 99-111. [CrossRef]

9. Kovačič, G.R.; Lesnik, M.; Vršič, S. An overview of the copper situation and usage in viticulture. Bulg. J. Agric. Sci. 2013, 19, 50-59.

10. Peña, N.; Antón, A.; Kamilaris, A.; Fantke, P. Modeling ecotoxicity impacts in vineyard production: Addressing spatial differentiation for copper fungicides. Sci. Total Environ. 2018, 616-617, 796-804. [CrossRef] [PubMed]

11. Speiser, B.; Berner, A.; Häseli, A.; Tamm, L. Control of Downy Mildew of grapevine with potassium phosphonate: Effectivity and phosphonate residues in wine. Biol. Agric. Hortic. 2000, 17, 305-312. [CrossRef]

12. Dagostin, S.; Schärer, H.-J.; Pertot, I.; Tamm, L. Are there alternatives to copper for controlling grapevine Downy Mildew in organic viticulture? Crop Prot. 2011, 30, 776-788. [CrossRef]

13. Weaver, D.K.; Subramanyam, B. Botanicals. In Alternatives to Pesticides in Stored-Product IPM; Subramanyam, B., Hagstrum, D.W., Eds.; Springer: Boston, MA, USA, 2000; pp. 303-320. ISBN 978-1-4613-6956-1.

14. Gurjar, M.S.; Ali, S.; Akhtar, M.; Singh, K.S. Efficacy of plant extracts in plant disease management. Agric. Sci. 2012, 3, 425-433. [CrossRef]

15. Mathew, L.K. Botanicals as biopesticides: A review. Int. J. Adv. Res. 2016, 4, 1734-1739.

16. Shuping, D.S.S.; Eloff, J.N. The use of plants to protect plants and food against fungal pathogens: A review. Afr. J. Tradit. Complement. Altern. Med. 2017, 14, 120-127. [CrossRef]

17. Choudhury, D.; Dobhal, P.; Srivastava, S.; Kundu, S. Role of botanical plant extracts to control plant pathogens. Indian J. Agric. Res. 2018, 52, 341-346. [CrossRef]

18. Prasanna, H.S.; Swami, D.V.; Bhagya, H.P.; Bhavishya; Shivakumar, S.N. Botanicals: Potential plant protection chemicals: A review. Int. J. Chem. Stud. 2018, 6, 217-222.

19. Yoon, M.-Y.; Cha, B.; Kim, J.-C. Recent trends in studies on botanical fungicides in agriculture. Plant Pathol. J. 2013, 29, 1-9. [CrossRef] [PubMed]

20. Bahlai, C.A.; Xue, Y.; McCreary, C.M.; Schaafsma, A.W.; Hallett, R.H. Choosing organic pesticides over synthetic pesticides may not effectively mitigate environmental risk in soybeans. PLOS ONE 2010, 5, e11250. [CrossRef]

21. Kaur, H.; Garg, H. Pesticides: Environmental impacts and management strategies. In Pesticides—Toxic Aspects; Soloneski, S., Ed.; InTech: London, UK, 2014; ISBN 978-953-51-1217-4.

22. Zaker, M. Natural plant products as eco-friendly fungicides for plant diseases control—A review. Agriculturists 2016, 14, 134-141. [CrossRef]

23. Moshi, A.P.; Matoju, I. The status of research on and application of biopesticides in Tanzania. Review. Crop Prot. 2017, 92, 16-28. [CrossRef]

24. Dagostin, S.; Formolo, T.; Giovannini, O.; Pertot, I.; Schmitt, A. Salvia officinalis extract can protect grapevine against Plasmopara viticola. Plant Dis. 2010, 94, 575-580. [CrossRef]

25. Schnee, S.; Queiroz, E.F.; Voinesco, F.; Marcourt, L.; Dubuis, P.-H.; Wolfender, J.-L.; Gindro, K. Vitis vinifera canes, a new source of antifungal compounds against Plasmopara viticola, Erysiphe necator, and Botrytis cinerea. J. Agric. Food Chem. 2013, 61, $5459-5467$. [CrossRef]

26. Thuerig, B.; Ramseyer, J.; Hamburger, M.; Oberhänsli, T.; Potterat, O.; Schärer, H.-J.; Tamm, L. Efficacy of a Juncus effusus extract on grapevine and apple plants against Plasmopara viticola and Venturia inaequalis, and identification of the major active constituent. Pest Manag. Sci. 2016, 72, 1718-1726. [CrossRef]

27. Thuerig, B.; James, E.E.; Schärer, H.-J.; Langat, M.K.; Mulholland, D.A.; Treutwein, J.; Kleeberg, I.; Ludwig, M.; Jayarajah, P.; Giovannini, O.; et al. Reducing copper use in the environment: The use of larixol and larixyl acetate to treat Downy Mildew caused by Plasmopara viticola in viticulture. Pest Manag. Sci. 2018, 74, 477-488. [CrossRef] [PubMed]

28. Ramseyer, J.; Thuerig, B.; de Mieri, M.; Schärer, H.J.; Oberhänsli, T.; Gupta, M.P.; Tamm, L.; Potterat, O.; Hamburger, M. Eudesmane sesquiterpenes from Verbesina lanata with inhibitory activity against major agricultural pathogen. In GA 2017-Book of Abstracts, Proceedings of the 65th International Congress and Annual Meeting of the Society for Medicinal Plant and Natural Product Research (GA 2017), Basel, Switzerland, 3-7 September 2017; Georg Thieme Verlag KG: Stuttgart, Germany, 2017. 
29. Thuerig, B.; Ramseyer, J.; Hamburger, M.; Ludwig, M.; Oberhänsli, T.; Potterat, O.; Schärer, H.-J.; Tamm, L. Efficacy of a Magnolia officinalis bark extract against grapevine Downy Mildew and apple scab under controlled and field conditions. Crop Prot. 2018, 114, 97-105. [CrossRef]

30. La Torre, A.; Righi, L.; Iovino, V.; Battaglia, V. Evaluation of copper alternative products to control grape downy mildew in organic farming. J. Plant Pathol. 2019, 101, 1005-1012. [CrossRef]

31. Leonard, C.M.; Viljoen, A.M. Warburgia: A comprehensive review of the botany, traditional uses and phytochemistry. J. Ethnopharmacol. 2015, 165, 260-285. [CrossRef]

32. Müller, S.; Salomo, K.; Salazar, J.; Naumann, J.; Jaramillo, M.A.; Neinhuis, C.; Feild, T.S.; Wanke, S. Intercontinental long-distance dispersal of Canellaceae from the New to the Old World revealed by a nuclear single copy gene and chloroplast loci. Mol. Phylogenet. Evol. 2015, 84, 205-219. [CrossRef]

33. Okello, D.; Komakech, R.; Matsabisa, G.M.; Kang, Y. A review on the botanical aspects, phytochemical contents and pharmacological activities of Warburgia ugandensis. J. Med. Plants Res. 2018, 12, 448-455. [CrossRef]

34. Olila, D.; Olwa-Odyek; Opuda-Asibo, J. Antibacterial and antifungal activities of extracts of Zanthoxylum chalybeum and Warburgia ugandensis, Ugandan medicinal plants. Afr. Health Sci. 2001, 1, 66-72.

35. Olila, D.; Opuda-Asibo, J.; Olwa-Odyek. Bioassay-guided studies on the cytotoxic and in vitro trypanocidal activities of a sesquiterpene (Muzigadial) derived from a Ugandan medicinal plant (Warburgia ugandensis). Afr. Health Sci. 2001, 1, 12-15. [PubMed]

36. Okello, D.; Kang, Y. Exploring antimalarial herbal plants across communities in Uganda based on electronic data. Evid. Based Complement. Altern. Med. 2019, 2019, 3057180. [CrossRef]

37. Okello, D.; Kang, Y. Ethnopharmacological potentials of Warburgia ugandensis on antimicrobial activities. Chin. J. Integr. Med. 2021, 27, 633-640. [CrossRef]

38. Frum, Y.; Viljoen, A.M.; Drewes, S.E.; Houghton, P.J. In vitro 5-lipoxygenase and anti-oxidant activities of Warburgia salutaris and drimane sesquiterpenoids. S. Afr. J. Bot. 2005, 71, 447-449. [CrossRef]

39. Frum, Y.; Viljoen, A.M. In vitro 5-lipoxygenase and anti-oxidant activities of South African medicinal plants commonly used topically for skin diseases. Skin Pharmacol. Physiol. 2006, 19, 329-335. [CrossRef] [PubMed]

40. Kubo, I. Antifungal sesquiterpene dialdehydes from the Warburgia plants and their synergists. In Structure and Chemistry (Part D); Elsevier: Amsterdam, The Netherlands, 1995; pp. 233-249. ISBN 9780444822659.

41. Kuglerova, M.; Tesarova, H.; Grade, J.T.; Halamova, K.; Wanyana-Maganyi, O.; van Damme, P.; Kokoska, L. Antimicrobial and antioxidative effects of Ugandan medicinal barks. Afr. J. Biotechnol. 2011, 10, 3628-3632.

42. Rugutt, J.K.; Ngigi, A.N.; Rugutt, K.J.; Ndalut, P.K. Native Kenyan plants as possible alternatives to methyl bromide in soil fumigation. Phytomedicine 2006, 13, 576-583. [CrossRef]

43. Taniguchi, M.; Chapya, A.; Kubo, I.; Nakanishi, K. Screening of east African plants for antimicrobial activity. Chem. Pharm. Bull. 1978, 26, 2910-2913. [CrossRef]

44. Wube, A.A.; Bucar, F.; Gibbons, S.; Asres, K. Sesquiterpenes from Warburgia ugandensis and their antimycobacterial activity. Phytochemistry 2005, 66, 2309-2315. [CrossRef]

45. Abuto, J.O.; Muchugi, A.; Mburu, D.; Machocho, A.K.; Karau, G.M. Variation in antimicrobial activity of Warburgia ugandensis extracts from different populations across the Kenyan Rift Valley. J. Micobiol. Res. 2016, 6, 55-64.

46. Kipanga, P.N.; Liu, M.; Panda, S.K.; Mai, A.H.; Veryser, C.; van Puyvelde, L.; de Borggraeve, W.M.; van Dijck, P.; Matasyoh, J.; Luyten, W. Biofilm inhibiting properties of compounds from the leaves of Warburgia ugandensis Sprague subsp ugandensis against Candida and staphylococcal biofilms. J. Ethnopharmacol. 2020, 248, 112352. [CrossRef]

47. Karani, L.W.; Tolo, F.M.; Karanja, S.M.; Khayeka-Wandabwa, C. Safety of Prunus africana and Warburgia ugandensis in asthma treatment. S. Afr. J. Bot. 2013, 88, 183-190. [CrossRef]

48. Madikane, V.E.; Bhakta, S.; Russell, A.J.; Campbell, W.E.; Claridge, T.D.W.; Elisha, B.G.; Davies, S.G.; Smith, P.; Sim, E. Inhibition of mycobacterial arylamine $\mathrm{N}$-acetyltransferase contributes to anti-mycobacterial activity of Warburgia salutaris. Bioorg. Med. Chem. 2007, 15, 3579-3586. [CrossRef]

49. Githinji, E.K.; Irungu, L.W.; Tonui, W.K.; Rukunga, G.M.; Mutai, C.; Muthaura, C.N.; Lugalia, R.; Gikandi, G.; Wainaina, C.W.; Ingonga, J.M.; et al. In vitro effects of Warburgia ugandensis, Psiadia punctulata and Chasmanthera dependens on Leishmania major promastigotes. Afr. J. Tradit. Complement. Altern. Med. 2010, 7, 264-275. [CrossRef]

50. Kubo, I.; Taniguchi, M. Polygodial, an antifungal potentiator. J. Nat. Prod. 1988, 51, 22-29. [CrossRef] [PubMed]

51. Rabe, T.; van Staden, J. Antibacterial activity of South African plants used for medicinal purposes. J. Ethnopharmacol. 1997, 56, 81-87. [CrossRef]

52. Geyid, A.; Abebe, D.; Debella, A.; Makonnen, Z.; Aberra, F.; Teka, F.; Kebede, T.; Urga, K.; Yersaw, K.; Biza, T.; et al. Screening of some medicinal plants of Ethiopia for their anti-microbial properties and chemical profiles. J. Ethnopharmacol. 2005, 97, 421-427. [CrossRef] [PubMed]

53. Saronjic, N. Biotransformation and Utilization of Drimane Sesquiterpenes by Endophytic Microorganisms. Master's Thesis, University of Vienna, Vienna, Austria, 2012.

54. Yibeltal, M.; Samuel, S.; Feleke, M.; Azamal, H. Antimicrobial activity of crude and semi-purified fractions of Warburgia ugandensis against some pathogens. J. Coast. Life Med. 2013, 1, 184-191. [CrossRef] 
55. Gabaston, J.; Richard, T.; Cluzet, S.; Palos Pinto, A.; Dufour, M.-C.; Corio-Costet, M.-F.; Mérillon, J.-M. Pinus pinaster Knot: A Source of Polyphenols against Plasmopara viticola. J. Agric. Food Chem. 2017, 65, 8884-8891. [CrossRef]

56. Mulholland, D.A.; Thuerig, B.; Langat, M.K.; Tamm, L.; Nawrot, D.A.; James, E.E.; Qayyum, M.; Shen, D.; Ennis, K.; Jones, A.; et al. Efficacy of extracts from eight economically important forestry species against grapevine Downy Mildew (Plasmopara viticola) and identification of active constituents. Crop Prot. 2017, 102, 104-109. [CrossRef]

57. Fang, Z.; Bhandari, B. Encapsulation of polyphenols-A review. Trends Food Sci. Technol. 2010, 21, 510-523. [CrossRef]

58. Borges, D.F.; Lopes, E.A.; Moraes, A.R.F.; Soares, M.S.; Visôtto, L.E.; Oliveira, C.R.; Valente, V.M.M. Formulation of botanicals for the control of plant-pathogens: A review. Crop Prot. 2018, 110, 135-140. [CrossRef]

59. Gent, D.H.; Schwartz, H.F.; Nissen, S.J. Effect of commercial adjuvants on vegetable crop fungicide coverage, absorption, and efficacy. Plant Dis. 2003, 87, 591-597. [CrossRef] [PubMed]

60. Green, J.M.; Beestman, G.B. Recently patented and commercialized formulation and adjuvant technology. Crop Prot. 2007, 26, 320-327. [CrossRef]

61. Dougoud, J.; Toepfer, S.; Bateman, M.; Jenner, W.H. Efficacy of homemade botanical insecticides based on traditional knowledge. A review. Agron. Sustain. Dev. 2019, 39, 37. [CrossRef]

62. Bagetta, G.; Cosentino, M.; Corasaniti, M.T.; Sakurada, S. Herbal Medicines: Development and Validation of Plant-Derived Medicines for Human Health; CRC Press: Boca Raton, FL, USA, 2012; ISBN 9781439837696.

63. Belwal, T.; Ezzat, S.M.; Rastrelli, L.; Bhatt, I.D.; Daglia, M.; Baldi, A.; Devkota, H.P.; Orhan, I.E.; Patra, J.K.; Das, G.; et al. A critical analysis of extraction techniques used for botanicals: Trends, priorities, industrial uses and optimization strategies. TrAC Trends Anal. Chem. 2018, 100, 82-102. [CrossRef]

64. Chrysargyris, A.; Kloukina, C.; Vassiliou, R.; Tomou, E.-M.; Skaltsa, H.; Tzortzakis, N. Cultivation strategy to improve chemical profile and anti-oxidant activity of Sideritis perfoliata L. subsp. perfoliata. Ind. Crops Prod. 2019, 140, 111694. [CrossRef]

65. R Core Team. R: A Language and Environment for Statistical Computing; R Foundation for Statistical Computing: Vienna, Austria, 2021.

66. Abbott, W.S. A method of computing the effectiveness of an insecticide. J. Econ. Entomol. 1925, 18, 265-267. [CrossRef] 